Geografiska Annaler: Series B, Human Geography

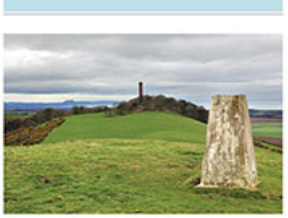

ISSN: 0435-3684 (Print) 1468-0467 (Online) Journal homepage: http://www.tandfonline.com/loi/rgab20

\title{
Ecologies of the self in practice - meditation, affect and ecosophy
}

\section{António Carvalho}

To cite this article: António Carvalho (2017) Ecologies of the self in practice - meditation, affect and ecosophy, Geografiska Annaler: Series B, Human Geography, 99:2, 207-222, DOI: 10.1080/04353684.2017.1306970

To link to this article: https://doi.org/10.1080/04353684.2017.1306970

曲 Published online: 31 Mar 2017.

Submit your article to this journal

Џll Article views: 116

View Crossmark data $₫$

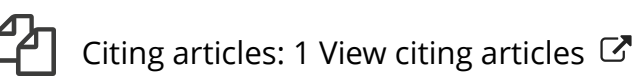




\title{
Ecologies of the self in practice - meditation, affect and ecosophy
}

\author{
António Carvalho \\ Centre for Social Studies, University of Coimbra, Coimbra, Portugal
}

\begin{abstract}
Drawing upon current concerns within non-representational and posthumanist theory, this paper explores the potential of meditation to trigger non-modern forms of affect. Supported by qualitative methodology which included participant observation at mindfulness and Vipassana retreats and semi-structured interviews with meditators, the paper analyses a number of subjective transformations characterized by struggle, embodiment, porosity and fragmentation. Following the call for deeper and more comprehensive forms of affect within ecosophy, the paper offers a step-by-step analysis of the emergence of meditative subjectivities, suggesting that they point towards ways of being in the world that challenge the autonomous modern self.
\end{abstract}

\section{ARTICLE HISTORY}

Received 18 April 2016

Revised 28 February 2017

Accepted 2 March 2017

\section{KEYWORDS}

Mindfulness; Vipassana; meditation; technologies of the self; ecosophy; affect

\section{Introduction}

This paper explores the possibilities of meditation to enact non-modern, decentred and ecological forms of affect. Meditation is a difficult concept to define, but it can be understood as referring to 'a family of techniques which have in common a conscious attempt to focus attention in a nonanalytical way and an attempt not to dwell on discursive, ruminating thought' (Shapiro 1984, 6). Following a qualitative approach, based on semi-structured interviews with Vipassana and mindfulness meditators, it is contended that the affective geographies of meditation - including particular performative, spatial and material reconfigurations - trigger forms of affect that contrast with the paradigmatic 'autonomous modern self (Stanley 2013, 70). It will be argued that these affectivities may support us in imagining 'new possibilities of life' (Harrison 2000, 498) which respond to the call for new subjectivities within ecosophy (Naess 1984; Sessions 1984; Devall 1995; Guattari 2000) and post-humanist literature (Stengers 2008; Pickering 2010), recognizing that destructive couplings between humans and the environment are illustrative of a modern ontology which also includes the self (Bateson 1972).

Recently, there has been an increasing interest in mindfulness within human geography (Lea, Cadman, and Philo 2015; Whitehead et al. 2015). Mindfulness is a process of non-judgemental awareness to moment-to-moment experience, including sensations, emotions, thoughts and movements (Kabat-Zinn 1991). Secular forms of mindfulness are a translation of ancient practices of meditation, which have been modernized and appropriated by the 'psy sciences' (Rose 1998), turned into popular medical applications such as MBSR (Mindfulness-Based Stress Reduction) and MBCT (Mindfulness-Based Cognitive Therapy).

Lea, Cadman, and Philo (2015) analysed a wide range of daily life transformations fostered by mindfulness, drawing upon semi-structured interviews with meditators and contributing to the field of habitual geographies. Their research challenges Nick Crossley's (2001) considerations on 
self-reflection, a type of dialogue with the self that is supported by language. Lea, Cadman, and Philo $(2015,57)$ argue that

The reflexive self of mindfulness meditation (...) offers a different model of transformation: while Crossley's reflexive self entails willing transformation in the self, mindfulness meditation absolutely does not involve this kind of will to transformation, but rather the transformation of the relationship to the self as it is.

This transformative process, described by Pagis as embodied self-reflexivity (Pagis 2009) is, as the authors argue, marked by an attempt to become aware of the 'automatic pilot in their thoughts, feelings and actions' (Lea, Cadman, and Philo 2015, 53). Becoming aware of mind wandering, instead of identifying with it, paves the way for a new mindful habit which allows practitioners to deal with stressors and life events in a more compassionate and positive way.

In '(Re)Inhabiting awareness: geography and mindfulness', Whitehead et al. (2015) present the results of a pioneering mindfulness programme which was delivered to UK civil servants. The authors draw interesting comparisons between mindfulness and post-structural geography, arguing that this practice can be recruited as a research strategy to support social scientists in the investigation of affect and embodiment. The methodological implications of mindfulness are exemplified by what they characterize as 'mindful interviewing', 'short mindfulness practices before certain interviews' (Whitehead et al. 2015, 566) and 'the more deliberate cultivation of bare attention during the interview process itself (Whitehead et al. 2015, 566). According to the authors, mindfulness generates a psychic space which facilitates the conduction of intersubjective research, increasing the 'awareness of the researcher's analytical and emotional relationship with the research project of which they are a part' (Whitehead et al. 2015, 567).

Whitehead et al. not only recognize the methodological potential of mindfulness but also its political significance. The authors argue that mindfulness can lead to psychological empowerment, in the sense that 'participants noticed that mindfulness had enabled them to become more aware of some of the unconscious and embodied dimensions of their decision-making' (Whitehead et al. 2015,570 ) and 'facilitated some agency (or sense of control) over these behaviours' (Whitehead et al. 2015, 570). Since their study was conducted with civil servants, there is also the possibility that mindfulness will trigger significant long-term changes in terms of public policy.

Geographical research on mindfulness addresses Harrison's call for a renewed attention to the sensate, 'that which is felt, experienced, and sensed' $(2000,498)$. This turn to the sensate transcends habits. As Harrison $(2000,509)$ states, 'habits solidify embodiment and thus the flux of everyday life, allowing for doubt to end in a shared form of life'. In order to recognize the sensate, more-thanhuman dimensions of everyday life, 'everyday feelings, sensations, and modes of experiencing must be considered against their "personalisation" and then dismissal' (Harrison 2000, 514), and these can potentially 'disclose new worlds' (Harrison 2000, 513).

Harrison's insights on the sensate and corporality have profound implications for the study of mindfulness and contemplative practices in general, suggesting that aspects such as vulnerability, sensitivity and stillness (2009) challenge Western logocentric tradition (Derrida 1976) and can pave the way for a new kind of politics - 'This moment of stillness then, of declining and remaining aside, represents, for me, the anarchical and all but silent condition of possibility for all political strategy as such' (Harrison 2009). These reflections remind us of Foucault's considerations on politics and the self, in the sense that 'there is no first or final point of resistance to political power other than in the relationship one has to oneself (Foucault 2006, 252).

Within non-representational geography, there has been a growing concern with new forms of politics and affect which take into account dimensions of embodiment, aesthetics and the sensate (Harrison 2000, 2009; Thrift 2000, 2004; Anderson 2002; McCormack 2002; Lea 2009; Ash 2013). Thrift $(2004,71)$ called for the development of a micropolitics of affect and of the subliminal, 'a microbiopolitics which understands the kind of biological-cum-cultural gymnastics that takes place in this realm which is increasingly susceptible to new and sometimes threatening knowledge and technologies'. According to Thrift $(2004,72)$, this microbiopolitics should include three relevant components: 
One is quasi-Foucauldian and consists of attention to the arts of the self of the kind already signalled. The second is an 'ethic of cultivation', an ethico-political perspective which attempts to instil generosity towards the world by using some of the infrasensible knowledges that we have already encountered on a whole series of registers (...). The third involves paying much greater attention to how new forms of space and time are being constituted.

Thrift's exploration of new affective practices includes Bill Viola's video art, while Ben Anderson's immanent utopianism is supported by music listening, which serves to highlight the 'apparently inconsequential "daily" geographies of hope' (Anderson 2002, 212). Current work in non-representational theory, including McCormack's exploration of 5 Rhythms, a contemporary somatic practice, indicates that there is a 'mutual implication of ethics and aesthetics' (McCormack 2002, 470) and that politics is always a micropolitics of affect.

These reflections on affect and politics are informed by Foucault's concerns with the constitution of ethical subjects, part of his research on technologies of the self (Foucault 1988), which highlights the intertwinement between self-knowledge and the care of the self (Foucault 2006). These technologies - such as forms of meditation, diets and a variety of exercises - transform human agents, allowing them to increase their lifespan, to embrace specific sets of ethical frameworks and to develop new physical abilities, supporting them in the attainment of 'happiness, purity, wisdom, perfection, or immortality' (Foucault 1988, 18). Foucault's initial reflections on the topic were focused on ancient Greek and Christian practices. However, the historical ramifications of these technologies affected psychoanalysis, models of confession and the human sciences in general (Foucault 2006). Foucault's work on the self was not limited to these 'individual' practices of subjectivity. Technologies of power (Foucault 1988) such as discipline also work through the reconfiguration of the body and affect, resorting, for instance, to anatomo-chronological schemes of behaviour, particular movements, gestures, and ways of instrumentally coding the body (Foucault 1995, 157).

The contemporary dissemination of practices of meditation, in particular mindfulness, has been the subject of much critique within social sciences. The proliferation of such practices in the West is usually understood according to the framework of secularization, de-traditionalization and the new age movement (Heelas 1996; Brown and Leledaki 2010), intimately linked to the psychologization, medicalization and commodification of religion (Lasch 1979; Carrette and King 2005; Carrette 2007; Brown and Leledaki 2010). Mindfulness practices have been considered the new opiate of the masses (Dawson and Turnbull 2006), technologies of neoliberal subjectification (Rose 2007; McMahan 2008; Mckay 2013) that 'serve' the capitalist establishment (Zizek 2005). These techniques have been characterized as devices to enhance well-being and 'happiness', the tenets of contemporary forms of governmentality (Binkley 2011; Mckay 2013).

As Davies $(2015,8)$ argues, 'the future of successful capitalism depends on our ability to combat stress, misery and illness, and put relaxation, happiness and wellness in their place'. Mindfulness, according to Kristin Barker, is a type of do-it-yourself medicalization by expanding the meaning of disease beyond mainstream medicine, since individuals internalize mechanisms of inner vigilance which medicalize every aspect of their lives - 'it [mindfulness] permanently locates individuals within a disease therapy cycle' $(2014,168)$. Stanley $(2012,632)$, recognizing that secular mindfulness is currently a commodified and individualized practice within modern capitalism, suggests that relevant ethical and ontological notions - including interdependence - should be mobilized 'as a way of counteracting the individualism of modern spiritual capitalism' and 'cultivating a critically distant stance towards the status quo of society and social values'. According to Stanley $(2013,70)$, the contribution of Buddhism to social change is supported by the insight of Interbeing (see Section 2), which has "been paralleled with social constructionist notions of "relationality", "joint action", and "co-action" because they are all theories undermining the existence of abiding independent entities'. Forbes (2012), drawing upon this Buddhist focus on interdependence, even suggests that mindfulness should be 'occupied', in the sense that it can promote a 'radical, activist worldview and practice that gives the lie to self-centered seekers of power over others, be it personal, corporate, or collective'. 
In fact, one of the schools of meditation that this paper analyses is led by Thich Nhat Hanh, who draws precisely on the notion of interdependence to re-imagine the social world and to tackle environmental issues (Manga 2008; Hanh 2013). This indicates that somatic and affective practices are not necessarily a reflection of cultural disenchantment but can be 'apprehended as one of many sites in which a pragmatic concern with the enlivening performance of the present can perhaps provide new modes of ethical and aesthetic inhabitation' (McCormack 2002, 473).

In this paper, it is contended that practices of meditation can offer interesting alternatives to modern forms of affective and aesthetic inhabitation. By progressively suspending a stable, autonomous sense of self, individuals embrace ontological formations which privilege embodiment, the sensate and interdependence. My interest in the potential of meditation to enact non-modern forms of affect is also informed by concerns with ontology within science and technology studies, my field of study. It has been argued that reality is enacted through a number of couplings between heterogeneous actors (Barad 2003; Haraway 2003; Latour 2005), which has generated concerns with the politics of ontology (Mol 2002; Pickering 2010), the kinds of worlds that should be brought into existence through these couplings.

This concern with ontology is not only descriptive - resulting in decentred forms of describing and assembling the social which recognize the role played by the more-than-human (Callon 1986; Pickering 1995; Latour 2005) - but also assumes a normative dimension. This 'ontological normativity' is translated into attempts to promote practices and assemblages which, instead of maintaining modern separations between humans and nonhumans, rather explore these dances of agency (Pickering 1995) to enact ways of inhabiting the world which are interactive, collaborative and sensitive to the more-than-human. In that sense, ontology is not necessarily a way of 'explaining' how the world works but a continuous political attempt to transform associations, technologies and practices.

These ontological concerns also extend to the self. In fact, as Thrift $(2004,59)$ suggests, 'the experiments with a "cosmopolitics" of new kinds of encounters and conviviality must include affect'. Attempts to enact new cosmopolitics must, then, question the autonomous modern self (Stanley 2013), characterized by agency, cognition and by its separation from other selves and the environment (Pickering 2010). If modern enactments of the self rely on habits, practices and affective geographies which solidify these dualisms, non-modern ontologies of affect are vulnerable to the sensate, embodiment and otherness, to the 'contingency of all becomings' (Venn 2010, 153). Since ontologies are malleable and performative, the modern self is not a historical precondition, in the sense that various practices and forms of affect can coexist within the same period.

Recognizing that selfhood is deeply entwined with habits and technologies, in this paper I am concerned with forms of affect that point towards relational and decentred forms of subjectivity. This is where I believe that there are strong connections between non-representational theory, post-humanism and ecosophy. Within deep ecology, there have been various attempts to explore alternatives to the autonomous modern self. The term 'deep ecology' was coined by Arne Naess in 1973. In the paper 'The Shallow and the Deep, Long Range Ecology Movements: A summary', Naess defined ecosophy as 'a philosophy of ecological harmony or equilibrium' $(1973,99)$ and characterized deep ecology as an approach which privileges 'the relational, total-field image' (Naess 1973, 95). Naess (1987, 35) argued that deep ecology should bring forward an ecological self, suggesting that environmentalism should be supported by forms of identification with nonhumans: 'because of an inescapable process of identification with others, with growing maturity, the self is widened and deepened. We "see ourselves in others". Ecosophical subjectivities are attained through the identification with all living beings, allowing humans to abandon a dualist and shallow version of the self (Naess 1984; Sessions 1984).

Naess resorts to various religious and contemplative traditions to find instances and examples of these processes of identification (1984), and the couplings between deep ecology, spirituality and meditation are well documented (Devall and Sessions 1985; Macy 1991; Fox 1993). John Seed and Joanna Macy, deep ecologists involved in environmental activism, developed an exercise called 'The Council of All Beings', inspired by various shamanic and contemplative traditions, which 
promotes the identification with nonhumans. The aim is to empower those who participate in these workshops - many of them involved in the anti-nuclear movement or in campaigns to protect the rainforest - allowing them to embrace a wider sense of self in order to better deal with their social struggles (Seed, Macy, and Fleming 1988).

These concerns within deep ecology with a wider, deeper sense of self also remind us of Gregory Bateson's insights on the roots of the ecological crisis. According to Bateson, one of the epistemological fallacies of the modern world is the separation between mind and nature. Bateson (1972, 496) suggested that '(wrong) ideas about the nature of man and his relation to the environment' are one of the causes of the ecological crisis, in the sense that 'when you separate mind from the structure in which it is immanent, such as human relationship, the human society, or the ecosystem, you thereby embark, I believe, on fundamental error, which in the end will surely hurt you' (493). Following Bateson, Guattari $(2000,68)$ called for the development of three ecologies - environmental, social and mental - arguing that 'we need new social and aesthetic practices, new practices of the Self in relation to the other, to the foreign, the strange'. According to Shaw $(2015,168)$, Bateson and Guattari invite us to rethink the relationship between earth and subjectivity, bringing 'an ethico-political orientation of responsibility towards the earthed and worldly subjectivity'. As it will be argued throughout this paper, meditative practices challenge modern configurations of affect, and can be considered ecosophical aesthetic practices by triggering decentred forms of selfhood, as the empirical vignettes will illustrate.

Following these remarks, this paper offers a step-by-step analysis of the transformations of affect linked to practices of meditation. Instead of focusing on secular versions of mindfulness, widely analysed by social scientists, it draws upon empirical material stemming from interviews and participant observation at Zen and Vipassana retreats. Although it has already been argued that contemplative practices challenge the autonomous modern self (Stanley 2013), there is very limited scholarship reflecting on the ecosophical potential of meditation from non-representational and post-humanist perspectives. Understanding ecology as a displacement from solid, habitual and stable forms of affect, this paper is focused on the difficulties and experiences of retreat participants, who progressively attempt to incorporate meditative - one could say wider, or deepened - forms of subjectivity.

This paper aims at contributing to current geographical scholarship concerned with new forms of ethical and aesthetic inhabitation (McCormack 2002), namely research specifically centred on meditative and yogic practices of the self (Lea 2009; Lea, Cadman, and Philo 2015; Whitehead et al. 2015; Lea, Philo, and Cadman 2016), and non-representational and post-humanist literature focused on embodied and non-modern forms of subjectivity (Harrison 2000, 2009; Thrift 2000, 2004; Anderson 2002; McCormack 2002; Stengers 2008; Pickering 2010).

Following this introduction, Section 2 of this paper presents the case studies, mindfulness and Vipassana, and explores some of the methodological difficulties associated with the empirical research of meditation, elaborating on how the data is organized and analysed. Section 3, 'Struggling to meditate', explores a number of difficulties reported by participants, focusing on various struggles which include the inability to deal with mind wandering or the intense pain triggered by sitting for a long time. Section 4 focuses on a number of affective changes which include a greater awareness of the present moment, heightened body consciousness, the emergence of novel sensations and a greater appreciation of the environment. Section 5 analyses a number of challenging episodes which expose meditators to vulnerability, the sensate and the explosion of affect, thus providing interesting alternatives to the paradigmatic modern self. In the conclusion, I reflect on the ecosophical dimensions of meditative affect, highlighting some of the ambiguities and limitations of this paper.

\section{Case studies and methodology}

The first case study is a form of Insight Meditation, or Vipassana, according to the instructions of the late Burmese teacher S. N. Goenka. This practice is taught in 10-day residential retreats and consists in paying attention to sensations throughout the body in a detached manner, usually characterized as 
equanimity - one should feel these sensations without conceptualizing, sitting in silence with the eyes closed. The goal is to reinforce embodiment (Pagis 2009; Whitehead et al. 2015), allowing subjects to become aware of the impermanent character of reality through the observation of sensations. Through the insight of impermanence, practitioners should realize that the self is an emergent process and that suffering is generated due to the reification of a bounded, hypostatized version of subjectivity.

The second case study concerns the mindfulness practices proposed by Thich Nhat Hanh, a Vietnamese Zen master currently living in Plum Village, a retreat centre in the south of France. These exercises are applied throughout everyday life activities - sitting, walking, washing the dishes, talking, working - thus constituting a form of engaged Buddhism, of which Hanh is the main proponent (Queen and King 1996). Practitioners are invited to constantly come back to the breath and to become aware of the present moment. Bells of mindfulness are strategically placed and activated in Thich Nhat Hanh's meditation centres - when practitioners hear them, they stop and come back to the breath, focusing on the present moment. Progressively, practitioners should develop the ability to identify in the environment metaphorical bells of mindfulness, allowing external reality - such as trees, the sky, the steam generated by boiling water - to become meditation teachers, reinforcing their contemplative status. Practitioners should also become increasingly aware of what Thich Nhat Hanh calls Interbeing, a concept which illustrates the constant interplay of reality and the iterative constitution of all becomings, challenging autonomous formations of affect. Entities are understood as being entangled, emerging through complex relational entanglements, inevitability reminding us of decentred understandings of ontology and affect (Harrison 2000; Blackman 2012) and highlighting the ecological dimension of meditation techniques.

Contemplative practices transform affect by challenging regular everyday habits (Lea, Cadman, and Philo 2015) - sitting, walking and eating - and by implementing novel somatic modes of attention (Csordas 1993), psycho-physiological forms of experiencing affect such as pleasure, hunger, anger and pain. Vipassana and Mindfulness install new ways of sitting, breathing and walking which aim at transforming affect, ideally enacting impermanent, porous and entangled subjectivities.

In order to analyse meditative reconfigurations of subjectivity, this paper will draw upon a popular approach in science and technology studies, based on Pickering's Mangle of Practice (1995). It will be argued that, in order to transform their regular habits, practitioners engage in dances of agency with meditative assemblages - set-ups, practices, meditative paraphernalia - to be able to tune in on meditative affordances - feeling the body as impermanent vibrations, becoming fully present to the present moment, suspending mental rumination, etc. The implementation of meditative habits and somatic modes of attention triggers resistance. According to Lea $(2009,74)$, following Foucault (2006), these resistances and struggles turn the care of the self into a permanent battle. By working on themselves, practitioners may experience novel forms of affect which suspend habitual ways of being in the world, turning them vulnerable to the sensate, the other and the more-thanhuman. This vulnerability allows us to read meditative practices as a form of ontological theatre (Pickering 2007) by contributing to a non-representational and non-modern imaginary of affect. These affective intensities can be understood as ecological since they allow practitioners to disassemble an autonomous version of subjectivity. In that sense, in this paper it is contended that meditative technologies - instead of merely being a set of practices appropriated by the disenchanted neoliberal discourse of well-being and happiness (McMahan 2008; Barker 2014; Davies 2015) - can actually contribute towards a non-representational and ecological imaginary of subjectivity, by allowing practitioners to progressively become vulnerable to affect and otherness.

This paper relies on data drawing from participant observation conducted between 2010 and 2013 at mindfulness and Vipassana retreats in the UK, France and Portugal. Twenty-seven participants were interviewed, some of them long-term meditators, with more than 15 years of serious practice (all names have been changed to ensure their anonymity). Relevant literature was analysed and the author also reflected on his own experiences with these practices. For a beginner with no previous experience with meditation, attending retreats was a very challenging endeavour, and the 
ethnographic work was sometimes complicated due to the delicate nature of the topic. I kept a diary where I attempted to register the most relevant events and affective changes, and since writing is forbidden at Vipassana retreats this had to be done undercover. As Scarry $(1985,12)$ recognizes, 'the relative ease or difficulty with which any given phenomenon can be verbally represented also influences the ease or difficulty with which that phenomenon comes to be politically represented'. Meditative experiences often escape verbal descriptions, which has generated various methodological problems for meditation research (Varela and Shear 1999). This lack of discursive representation, coupled with the disciplinary and disruptive characteristics of retreats as affective atmospheres (Ash 2013), often allows pastoral authorities (such as meditation teachers) to colonize phenomenological descriptions with inner maps and cosmogonies. This raises various questions regarding the relationship between discipline, authority and liberation (Lea 2009; Lea, Philo, and Cadman 2016). In order to explore the implementation of meditative habits, the following section is focused on the 'struggles' triggered by these technologies of the self.

\section{Struggling to meditate}

Going on retreat (especially for the first time) is a challenging experiencing. Preston (1981), following Becker's analysis of becoming a marijuana smoker (Becker 1953), argued that a similar process is involved in order to fully experience the 'effects' of meditation. The implementation of new habits, linked to technologies of the self, generates struggles (Lea 2009) which, in the case of meditation, are marked by the inability to be fully present, since participants are overwhelmed by mind wandering. As Lea, Cadman, and Philo $(2015,53)$ argue, 'the hinge of the [mindfulness] techniques is to teach the participants to recognize when their minds are running on automatic pilot'.

Since meditation involves the reconfiguration of regular habits of the self in geographies characterized by silence and the reduction of external stimuli, the meditator's mind produces a vast set of resistances which allow practitioners to fully experience task-unrelated-thoughts (Smallwood, Obonsawin, and Heim 2003). Recently, there has been an increased interest in the study of mind wandering and mental activity that is self-generated (Callard et al. 2013). Meditation and sensory deprivation suspend the plethora of environmental stimuli that characterize Western metropolitan life, and when the mind is deprived of external objects, it rebels and creates a number of images, memories, desires, instead of slowing down. As Joanna, a Vipassana meditator, puts it:

As soon as you sit cross legged, and you start focusing the mind on the breath, the mind is in a state of turmoil, and wants to push away, and fight. (Interview, April 2012)

An informant recalls that during his first Vipassana retreat he felt like he was watching a film, since his mind resembled a movie screen preventing him from concentrating on the breath:

For the first two days my mind was like a screen, I was in this big cinema - there were so many different views, like mountains and rocks coming to sight. I was wondering what that was all about but it cleared up by the third day. (Interview, October 2011)

Ordinary states of consciousness are characterized by task-unrelated-thoughts, and sitting in meditation multiplies them. In order to implement a new technology of the self, practitioners are taught to accept these manifestations, resorting to the breath and to the awareness of sensations. Lewis, a practitioner of mindfulness, used the notion of resistance to illustrate his struggle with meditation, identifying impatience as one of the most habitual problems:

There is a resistance that for me is fundamental in meditative practices that is impatience. Impatience towards what? The impatience to focus on a given object ... being seated and wanting to walk ... the knee hurts and I want the pain to go away. (Interview, December 2011)

When impatience emerges and the mind becomes agitated, the performative apparatus of mindfulness can be mobilized: a gatha (short verses that remind participants of the entangled nature of 
reality) is repeated; a bell is activated; one comes back to the breath and feels whatever one is doing (such as brushing the teeth or walking). One develops a number of strategies of accommodation (Pickering 1995) to progressively become able to practice meditation. This can include recruiting nonhuman allies - such as cushions, pillows and bells- to support a new mode of somatic attention. In other cases, practitioners feel tempted to practice Yoga in order to endure longer periods of sitting meditation. Regarding mindfulness, gathas are particularly helpful. As Sal told me:

I use gathas when I don't feel peace, when I really have to come back to myself, sometimes I'm irritated with someone and my mind is thinking about that, so the gatha helps me come back ... arriving ... now ... (Interview, December 2011)

Participants struggle with their nonmeditative habits and feel overwhelmed by mind wandering. In order to deal with these multiple difficulties, a number of actions are undertaken, such as coming back to the breath, readjusting one's posture and recruiting nonhumans and specific sentences. One's resistance towards meditation and the affective geography of the retreat is particularly well illustrated in the case of Vipassana. Most of the interviewees mentioned they had to deal with intense pain. In order to develop equanimity towards sensations, participants are invited to become aware of this pain without reacting to it. On the fourth day of these retreats, participants are introduced to the infamous Adhitanna sittings, or sittings of strong determination. Practitioners are not supposed to move for one hour, the length of each meditation session, three times a day (although they are allowed to correct their posture).

Philip, recalling his first Vipassana retreat, mentioned that he had the feeling that the Vipassana organization was particularly sadistic for deliberately putting people through such intense pain:

I reached such a level of pain that I engaged in a fight with my unconscious ... I should leave ... because this is a sadistic organization... The teachers are in the room looking at everyone, watching them suffer. (Interview, September 2010)

During my second retreat, I had the distinct feeling that someone was stabbing me in the back due to the intense pain experienced. As a $\mathrm{PhD}$ student with a history of back pain and a sedentary lifestyle, trying not to move for an hour was particularly challenging. Vipassana geographies seem to rely on this direct, nonmediated experience of pain to test one's equanimity. As put by Rebecca:

I've had pain so severe I thought I wouldn't be able to walk, I am, like, worried about it, and eventually I'm like no, stop worrying .... and at the end of the hour the pain goes away, and I get up and walk out, and that wasn't a normal pain, it's like a Vipassana pain. (Interview, April 2012)

Pain emerges as a resistance to these affective reconfigurations and is explicitly mobilized by the contemplative apparatus as an opportunity to implement a new habit of the self. Moreover, it also allows practitioners to directly deal with physical suffering, fostering what Pagis coins as embodied self-reflexivity (2009). The intensities of pain rescue meditators from the overwhelming stream of consciousness and mind wandering, '(...) bringing about an immediate reversion to a state anterior to language, to the sounds and cries a human being makes before language is learned' (Scarry 1985, 4).

\section{Embodying meditation}

In this section, we explore how the continuous practice of meditation progressively implements new forms of affect, characterized by the slowing down of the flow of thoughts, increasing the awareness of the body and fostering a deeper sense of connection with others. These experiences allow practitioners to develop a new appreciation towards their embodied experience, instead of being overwhelmed by task-unrelated-thoughts, and are an important step towards the development of ecological forms of subjectivity, turning the body more sensitive to more-than-human agencies and energies (Leledaki 2007; Philo, Cadman, and Lea 2014), usually overlooked by modern versions of the self. 
Rebecca, a Vipassana meditator, recalled that she often experiences 'mental silence' when she practices Anapana [awareness of the breath] in longer Vipassana retreats:

Sometimes you start to approach mental silence, especially when you're doing Anapana, and the thoughts come up every five or ten minutes and you're like ... oh, there's a thought, and then it's gone again, and then there's a big gap of silence. (Interview, April 2012)

Meditation slows down the flow of thoughts that characterizes ordinary states of consciousness. Practitioners consider this aspect highly beneficial, in the sense that they are able to observe and turn thoughts into less destructive mental formations, as Sean, a mindfulness meditator, told me:

Meditation has the capacity to slow down the flow of thoughts, so I'm able to see more clearly what is that I'm thinking. Before I came here I knew I was suffering but I wasn't able to see clearly the content of my thoughts, on a moment to moment basis, and meditation to me has given that clarity of seeing what I'm actually thinking and gives me an opportunity to change them. (Interview, February 2011)

Although Sean's words apparently illustrate the medicalization of his experiences with meditation, they do not necessarily indicate that his practice has been commodified by the neoliberal psy sciences. As Lea $(2009,74)$ argues, while reflecting on the therapeutic dimension of yoga and technologies of the self in general, "The "curative and therapeutic" function suggests that we need to live the best form of life that we possibly can.' Through this ongoing battle, practitioners are able to observe the content of thoughts without reacting, de-identifying with the stream of consciousness and increasing the awareness of the sensate. In the case of Vipassana meditation, this attention towards the sensate is marked by the emergence of a subtle feeling which often permeates one's body. Practitioners describe this feeling by resorting to a variety of words and expressions such as tingling, flowing water, pins and needles, static electricity, energy, vibrations, etc. This often means that, when meditators are asked to describe their experiences, they usually report a novel appreciation towards sensations throughout their bodies, which can take them by surprise. As put by Adam:

A pattern would be established ... in the face ... spreading in all directions, radiating something like if small drops of water were being spread out by the wind in the air ... it was sort of a pulsation of these sensations, like if there were hundreds of channels on the surface of the skin that would originate in the centre of the face and then would spread out through all my face, the neck, the cheeks, the chin, the ears .... (Interview, December 2011)

The development of a new somatic mode of attention rescues practitioners from the endless cycle of mind wandering, resulting in an increasing awareness of sensations. This attunement to embodied experience is often described by resorting to natural images and metaphors. The meditative body is progressively porous to the sensate and the more-than-human. As Thrift $(2000,49)$ suggests, contemplative practices 'expand the bio-political domain' and indicate that the world has not been 'disenchanted': '(...) the mystical qualities of the world remain in place. Assured by a whole series of body practices, some old and some new, these practices have produced an expansion of awareness of present time' (Thrift 2000, 35). Meditative practices of the self bring forth vitalist forms of affect, turning participants porous to sensations and energies. As Joanna, a very experienced Vipassana meditator stated:

Passing the awareness over a particular part with a particular sensation, it doesn't matter, but very often there will be a sensation, a flow above it, because that sensation is always there, but the mind can't feel it. So, by passing over a gross sensation, there may or may not be tingling present over the surface of that. And a visual image that I often will get when I'm having these experiences is almost like a river, and what you might have is maybe a bolder or ... a rock, and the water is just skimming over the top of the rock ... (Interview, April 2012)

Joanna's words indicate that Vipassana meditation enacts a version of the body filled with vibrations, more vulnerable to the multiple intensities affecting it. The body is no longer a solid mass separated from the environment, and the practitioner is aware of these sensations in an embodied way. In the case of Thich Nhat Hanh's approach, there is also an attempt to explicitly expand this awareness into all aspects of everyday life. As Ted stated: 
There's no difference between sitting or not sitting. You can say that the sitting ends with the bell, but in this practice it does not end when we stand up, it's about the awareness of what you are doing. Most of the time we are distracted by our thinking, while here we try to become aware ... (Interview, February 2011)

This heightened awareness is linked to the performative modifications operated by mindfulness, including walking meditation. Subjects should become aware of the present moment; this includes not only the moving and relational body but also thought patterns and the environment that surrounds them. This kinaesthetic appreciation is materialized in practices such as walking and eating meditation, which explicitly emphasize the contemplation of nature and the deep interconnection between all entities (Carvalho 2014). The aim is to prompt an ecological or decentred form of selfhood which translates into a deepened sense of connection with other humans and nonhumans. Some of the mindfulness practitioners I interviewed were deeply involved in environmentalism, and justified their social and political action due to their experiences with meditation. According to Peter, a meditation teacher I had the chance to interview:

I have seen many people with ecological concerns start a meditation practice, but I also see it the other way around, people who have experiences with meditation becoming interested in environmental and ecological issues, in a more encompassing ethic, including not only humans but also the environment, animals, the world ... that is clear to me, and it is one of most notable and exciting aspects of meditation, that deep interpenetration between those two dimensions, meditation and the nonhuman world, an interest and a respect ... a consideration and a deeper ethical care regarding other living beings and the natural world in general, that is very clear. I believe that the experience of meditation makes us realize that we are not separate, we are not separate from anything or anyone, we are not separate from any form of life, whether animate or inanimate, the meditative experience allows us to feel the non-separateness between what we call the self and the world. (Interview, May 2013)

As suggested by Peter, this sense of non-separateness is at the core of meditative experience. The suspension of a bounded, autonomous version of the subject supports ecosophical ways of being in the world. Michael, a highly experienced mindfulness practitioner and teacher who is also an environmental activist, told me that meditation transformed his perception in such a way that now he feels more 'connected':

It [mindfulness] affects everything - in terms of perception, in terms of how I contact with nature - it makes us much more humble and much more respectful and to value very deeply the contact with nature and with other people. I suppose on a general level it's a kind of deepening experience, you feel more connected with other things in your environment and through practice you see more deeply and you feel more deeply that connection. (Interview, May 2011)

Michael's remarks support the assumption that mindfulness brings forth a heightened sense of connection which resonates with ecosophical models of the deeper or comprehensive self. This increasing awareness is not limited to the body but also includes the environment, reinforcing the couplings between ethics and aesthetics (McCormack 2002).

The affective changes operated by meditation are also marked by the emergence of experiences which turn practitioners vulnerable to the explosion of the sensate and challenge cognition. The aim of the following section is to explore in detail some of these unusual experiences, arguing that by suspending the modern, autonomous self, meditative geographies allow the emergence of decentred and ecosophical forms of subjectivity.

\section{Beyond the modern self}

This section explores episodes where practitioners became passive and vulnerable to meditative agency. These states of passivity indicate that individuals became overwhelmed by the flows of meditative becoming, and were no longer in control. They became beyond habit, and were fragmented by explosions of affect - 'through the disturbance of habits, sensation becomes the basis of disclosing new worlds' (Harrison 2000, 498). These states of sensuous fragmentation allow practitioners to be moved by the more-than-human - subjects cry, their bodies tremble, they are rendered vulnerable 
by the porosity of affect. It is my contention that these episodes are profoundly ecosophical, as they de-stabilize the modern self and challenge autonomous formations of subjectivity, now deeply affected by the pathos of a multitude of sensations.

The first vignette we will explore concerns an episode reported by Eric Lerner, an American traveller who practiced Vipassana during the seventies and had an experience of dissolution, which in this tradition is referred to as Bangha:

Very quickly I was aware of my entire body as a field of particles... Then it seemed as if my mind was spread out through my entire body. Anywhere I focused I felt this single mist like sensation, and my mind felt as if it was being pulled into this fluid...

I was aware of the uniqueness of this sensation, and I wondered how I could describe it. Then as my mind started to phrase the answer, the conceptualizing stopped. The jaws of my chattering mind flapped open in silence. The commentator disappeared (Lerner 1977, 105).

Eric's experience was of the emergence of the body as a flow of vibrations. Eric also reports being 'pulled' into the fluid, indicating the passivity of the meditator, suggesting that his agency was suspended when Bangha emerged. The non-representational dimension of this experience is also interesting - when Eric states that 'commentator disappeared' one is led to believe that this episode assumed an almost non-cognitive characteristic, undermining its description.

Tim, a Vipassana practitioner, told me that he felt dissolution at least twice, and his description was particularly insightful:

On day ten of the first one [his first Vipassana retreat] I got a slight sensation of Bangha, [it] was like being in a jet when it takes off, and then a vibration, that was very strong, permeated my whole living world, it was fantastic. The second time I got that again, in the evening ... I was completely racked in pain, it was excruciating, but I felt like a slight sensation of being in a lift, I just felt the ground pushing up beneath me and I was like ... ok ... remain with equanimity, stay with the breathing and the sensations on the body, and then it was like the event horizon from 2001, everything in my body felt like it was miles and miles wide, and it was just light, just different colours of light, flashing up, everything was changing, and above that was my consciousness, as if my consciousness was looking down into my body, and I felt like I was having an out of body experience, so I opened my eyes and that was it, I couldn't get that back. (Interview, April 2011)

Tim's description illustrates the transient nature of bodily dissolution and the fact that it not linearly controlled by the meditator, indicating his passivity. The radically different nature of Bangha was particularly frightening, giving Tim a strong feeling of impermanence due to the experience of vibrations and suspending a stable sense of selfhood. The explosion of the sensate renders the meditator vulnerable and passive. According to some Vipassana meditators I interviewed, the heightened sensitivity towards sensations developed during the body scan is often accompanied by the difficulty to separate the body from the environment - vibrations assume, in that sense, a morethan-human characteristic.

Mitch, who spent a great deal of time practicing mindfulness, supported by Thich Nhat Hanh's gathas, told me that one day he decided to take a break from meditation. He started watching TV but was suddenly invaded by a strong feeling of presence which puzzled him:

The feeling of presence overtook me and suddenly I felt like I was there so entirely, so completely. It was definitely not a concentration, it was immensely free ... I washed my hands and it felt like the first time I ever washed them. I laughed with a slight hint of madness and cackled in tears of joy. I took a long time to look around the room and just looked with a sense of wonder. My vision was impeccably clear and there was nowhere to go and this was it... (Interview, June 2013)

The clarity mentioned by Mitch indicates that, for the first time, he was fully aware of the present moment. This overwhelming episode moved him, making him cry, and the fact that it emerged while he was not focusing on his mindfulness practice (he was watching TV) suggests that these states of passion are not mechanically induced by practitioners. This dimension of passivity is also present in an interesting episode that we can find in Kapleau's The Three Pillars of Zen (1989). It was experienced by a serious Canadian practitioner some years after she attended a series of retreats in Japan: 
I suddenly felt as though I were being struck by a bolt of lightning, and I began to tremble. (...) Tears gushed out and so weakened me I had to lie down. Yet a deep happiness was there ... Slowly my focus changed: 'I'm dead! There's nothing to call me! There never was a me! It's an allegory, a mental image, a pattern upon which nothing was ever modelled.' I grew dizzy with delight. Solid objects appeared as shadows, and everything my eyes fell upon was radiantly beautiful. (Kapleau 1989, 267)

What is interesting about this episode is that it took place while the subject was not meditating she was taken by surprise by a bolt of lightning and the autonomous self was suspended. Tears followed, and the pathos of meditative agency rendered the subject vulnerable. Another interesting aspect concerns the series of insights experienced by this meditator, namely the pervasiveness of a feeling of love without object - 'I feel a love which, without object, is best called lovingness' (Kapleau 1989, 268). Love can be understood as becoming vulnerable to the more-than-human explosion of the sensate. According to Manning $(2010,122)$, 'Affect moves being, dephasing being with respect to its individuality, causing it to overspill.' This overspill turns meditative subjectivities porous, accepting the intensities penetrating every entanglement. The deep happiness described by the participant indicates a growing sensitivity towards Interbeing, reinforcing the ecosophical dimension of meditation, illustrating its potential to expand the bio-political domain by fostering decentred forms of affect which go beyond the autonomous modern self.

\section{Conclusion}

The aim of this paper was to contribute to scholarly work in human geography and post-humanist theory by exploring practices of subjectivity which challenge the modern self. In order to do so, the paper focused on two practices of meditation, Vipassana and mindfulness. Much has been written on the commodification of secular versions of mindfulness under the auspices of neoliberalism; my approach, on the other hand, attempted to illustrate how practices of meditation challenge paradigmatic versions of the autonomous self, bringing forth embodied, porous and ecosophical forms of affect.

It was contended that these instances of meditative affect could be coined as ecological, reminding us of the work within ecosophy focused on deep and comprehensive forms of subjectivity, as well as of Bateson and Guattari's attempt to couple environmentalism with forms of affect which overcome dualism. As we have seen in the introduction, Naess and other deep ecologists have suggested that certain practices and contemplative traditions are helpful in the enactment of more comprehensive and ecosophical versions of subjectivity. Mindfulness and Vipassana meditation draw upon ontologies - impermanence and Interbeing - which are, in some cases, actively embodied by meditators, suspending their stable sense of self and challenging the dermal and cognitive barriers between self and the world. This can manifest in a heightened sense of presence, in the experience of body dissolution and in the fragmentation of the self.

Although meditative practices may, in fact, increase the sense of connection with other humans and nonhumans, therefore supporting environmental action (Section 4), one of the most interesting aspects of meditative affect is the fragmentation of a stable and autonomous sense of subjectivity. In fact, the episodes of vulnerability described in Section 5 go beyond mere identification, in the sense that the discovery of new worlds through meditative affect is marked by sensuous excess which challenges cognition and self-control. This allows us to re-imagine ecology as a relational attempt to break away from individuation, supported by technologies of the self which lead to a greater appreciation of the more-than-human dimensions of affect.

The emergence of meditative subjectivities requires the enactment of particular affective atmospheres (Ash 2013) which inevitably include the nonhuman (Harrison 2000) in order to invent new possibilities of life. Spatial reconfigurations, postural changes, specific regulations and a variety of actants (bells, cushions, etc.) are recruited to support participants in the development of meditative habits. These geographies of meditation trigger struggles which manifest as pain, impatience and in the difficulty to deal with mind wandering, as we have seen in Section 3. The continuous practice of 
these technologies of the self may then generate various affordances, including a greater awareness of the present moment and an increasing appreciation of the body and the environment. In some cases, participants report episodes which go beyond cognition and representation, and their sense of self is momentarily dissolved, allowing them to become vulnerable to the sensate beyond habit and subjectification.

The analysis, focusing on three phases of meditative affect, is not intended to convey the idea that meditation implies a linear progress. In fact, the 'evolution' of meditative practice is far from being linear, including 'periods of regression, restructuring and reintegration as part of the basic growth pattern' (Kornfield 1979, 53). This temporal ambiguity of meditation should also serve as a reminder to avoid simplistic remarks on its politics, stating, for instance, that secular versions of mindfulness are commodified and have been appropriated by neoliberalism, whereas traditional versions, by focusing on impermanence and interdependence, can potentially challenge contemporary socioeconomic formations.

This ambiguity also extends to the difficulties in coupling Foucault's remarks on technologies of the self with scholarly work within non-representational theory and post-humanism more generally. In fact, and although Foucault (2006) highlighted the important connections between self-knowledge and the care of the self, underlining the embodied and practical character of ancient philosophy, his archaeological analysis is concerned with the historical evolution of the self, whereas post-humanist approaches recognize that ontology is not necessary limited by historical frameworks. Ontology is more a style of being in the world than a pre-determined set of historical conditions, such as Foucault's epistemes (Foucault 1970). In that sense, technologies of the self should be rescued from a strictly historicist approach, recognizing that the autonomous modern self is not a historical formation of subjectivity but a way of being in the world which can be disrupted by geographies of meditation - and, as it was stated in the introduction, many technologies and models of the self can coexist at the same time.

Practices of meditation and their various affordances help us imagine a different way of being in the world, expanding the bio-political domain (Thrift 2000). As Shanon (2010, 278) suggests, nonordinary episodes should be understood as a kind of 'supreme music', rejecting positivistic interpretations of unusual experiences. Notions such as 'aesthetics of existence' (Foucault 1984) or 'somaesthetics' (Shusterman 1999) indicate that perhaps we can look at contemplative practices as engaged and embodied art forms, ways of performing affect which allow us to be moved by the sensate, reimagining ecology as an openness towards relationality, the more-than-human and the ineffable.

As Lea, Cadman, and Philo $(2015,61)$ recognize, 'intimate bodily experiences are invariably situated within wider space-time routines and contexts'. This means that the ecosophical and political scope of meditation depends on various temporal and geographical dimensions that structure our habits and affect our everyday life. The meditation retreat, as an ecosophical geography, recognizes the materiality and spatiality of affect, and by reconfiguring a number of associations it attempts to bring forth new subjectivities.

The geographical dimension of these ecosophical forms of affect reminds us that the permanent reconfiguration of spaces of power also triggers new forms of political and contemplative resistance. This obviously extends to the practice and reinvention of mindfulness at the time of the Anthropocene (Szerszynski 2014). As we witness the failure of our biological and technological life support systems, the renewed interest in contemplative exercises indicates that perhaps we can look at the decentred body of meditative technics as part a wider spectrum of ecological practice systems whose emergent character may allow us to contemplate and take care of our Anthropocenic ontologies.

These novel affective, agricultural, technological, political and social assemblages indicate that our hope can be supported by an immanent utopianism (Anderson 2002) which allows us to delve into the interplay of affect, vulnerability and the more-than-human, drawing attention to the transformative potential of ecosophical geographies. 


\section{Acknowledgements}

For very valuable feedback on this paper and their efforts in organizing this special issue, I thank Robert Shaw and Gerald Taylor Aiken. Richard Ek and the three anonymous reviewers were extremely helpful and introduced me to relevant perspectives and literature which informed the most recent version of this essay. I would also like to thank Andrew Pickering, Giovanna Colombetti, Brian Rappert, Dana Wilson-Kovacs and Isabel Roque for their comments on a previous draft of this paper. Finally, this paper would not exist without the contributions of the interviewees, who kindly agreed to share their personal experiences with meditation.

\section{Funding}

I would like to thank the Portuguese Foundation for Science and Technology for funding my PhD research (SFRH/BD/ 62928/2009).

\section{References}

Anderson, B. 2002. "A Principle of Hope: Recorded Music, Listening Practices and the Immanence of Utopia." Geografiska Annaler: Series B, Human Geography 84 (3/4): 211-227. doi:10.1111/j.0435-3684.2002.00125.x.

Ash, J. 2013. "Rethinking Affective Atmospheres: Technology, Perturbation and Space Times of the Non-human." Geoforum 49: 20-28. doi:10.1016/j.geoforum.2013.05.006.

Barad, K. 2003. "Posthumanist Performativity: Toward an Understanding of How Matter Comes to Matter.” Signs: Journal of Women in Culture and Society 28 (3): 801-831. doi:10.1086/345321.

Barker, K. 2014. "Mindfulness Meditation: Do-It-Yourself Medicalization of Every Moment." Social Science \& Medicine 106: 168-176. doi:10.1016/j.socscimed.2014.01.024.

Bateson, G. 1972. Steps to an Ecology of Mind. San Francisco, CA: Chandler.

Becker, H. 1953. "Becoming a Marihuana User.” The American Journal of Sociology 59 (3): 235-242. doi:10.1086/ 221326.

Binkley, S. 2011. "Happiness, Positive Psychology and the Program of Neoliberal Governmentality." Subjectivity 4: 371-394. doi:10.1057/sub.2011.16.

Blackman, L. 2012. Immaterial Bodies - Affect, Embodiment, Mediation. London: Sage.

Brown, D., and A. Leledaki. 2010. "Eastern Movement Forms as Body-Self Transforming Cultural Practices in the West: Towards a Sociological Perspective.” Cultural Sociology 4 (1): 123-154. doi:10.1177/1749975509356866.

Callard, F., J. Smallwood, J. Golchert, and D. S. Margulies. 2013. “The Era of the Wandering Mind? Twenty-first Century Research on Self-generated Mental Activity.” Frontiers in Psychology 4: 891. doi:10.3389/fpsyg.2013.00891.

Callon, M. 1986. "Some Elements of a Sociology of Translation: Domestication of the Scallops and the Fishermen of St Brieuc Bay." In Power, Action and Belief: A new Sociology of Knowledge?, edited by John Law, 196-223. London: Routledge.

Carrette, J. 2007. Religion and Critical Psychology. London: Routledge.

Carrette, J., and R. King. 2005. Selling Spirituality: The Silent Take Over of Religion. London: Routledge.

Carvalho, A. 2014. "Subjectivity, Ecology and Meditation: Performing Interconnectedness." Subjectivity 7 (2): $131-150$. doi:10.1057/sub.2014.3.

Crossley, N. 2001. The Social Body: Habit, Identity and Desire. London: Sage.

Csordas, T. J. 1993. "Somatic Modes of Attention." Cultural Anthropology 8 (2): 135-156. doi:10.1525/can.1993.8.2. $02 \mathrm{a} 00010$.

Davies, W. 2015. The Happiness Industry: How the Government \& Big Business Sold Us Wellbeing. London: Verso.

Dawson, G., and L. Turnbull. 2006. "Is Mindfulness the New Opiate Of the Masses? Critical Reflections from a Buddhist Perspective." Psychotherapy in Australia 12 (4): 60-64.

Derrida, J. 1976. Of Grammatology. Baltimore, MD: Johns Hopkins University Press.

Devall, B. 1995. “The Ecological Self.” In The Deep Ecology Movement: An Introductory Anthology, edited by Alan Drengson, and Yuichi Inoue, 101-123. Berkeley, CA: North Atlantic Books.

Devall, B., and G. Sessions. 1985. Deep Ecology: Living as if Nature Mattered. Salt Lake City, UT: Peregrine Smith.

Forbes, D. 2012. “Occupy Mindfulness.” Accessed 22 February 2017. http://beamsandstruts.com/articles/item/982occupy-mindfulness.

Foucault, M. 1970. The Order of Things: An Archaeology of the Human Sciences. New York: Pantheon Books.

Foucault, M. 1984. "What is Enlightenment?.” In The Foucault Reader, edited by Paul Rabinow, 32-50. New York: Pantheon Books.

Foucault, M. 1988. “Technologies of the Self." In Technologies of the Self: A Seminar with Michel Foucault, edited by Luther H. Martin, Huck Gutman, and Patrick H. Hutton, 16-49. Amsherst: The University of Massachusetts Press.

Foucault, M. 1995. Discipline and Punish. New York: Vintage Books.

Foucault, M. 2006. The Hermeneutics of the Subject - Lectures at the Collège de France 1981-1982. New York: Picador. 
Fox, W. 1993. “Transpersonal Ecology.” In Paths Beyond Ego, edited by Roger Walsh, and Frances Vaughan, $240-241$. New York: Penguin Putnam Inc.

Guattari, F. 2000. The Three Ecologies. New Jersey: Athlone Press.

Hanh, T. N. 2013. Love Letter to the Earth. Berkeley, CA: Parallax Press.

Haraway, D. 2003. The Companion Species Manifesto: Dogs, People, and Significant Otherness. Chicago, IL: Prickly Paradigm Press.

Harrison, P. 2000. “Making Sense: Embodiment and the Sensibilities of the Everyday." Environment and Planning D: Society and Space 18 (4): 497-517. doi:10.1068/d195t.

Harrison, P. 2009. “Remaining Still.” M/C Journal 12 (1) Accessed 22 February 2017. http://journal.media-culture.org. au/index.php/mcjournal/article/viewArticle/135.

Heelas, P. 1996. The New Age Movement. Oxford: Blackwell.

Kabat-Zinn, J. 1991. Full Catastrophe Living. New York: Delta Trade Paperbacks.

Kapleau, P. 1989. The Three Pillars of Zen. New York: Anchor Books.

Kornfield, J. 1979. “Intensive Insight Meditation: A Phenomenological Study.” Journal of Transpersonal Psychology 11 (1): 41-58.

Lasch, C. 1979. The Culture of Narcissism. New York: W. W. Norton \& Company.

Latour, B. 2005. Reassembling the Social - An Introduction to Actor-Network-Theory. New York: Oxford University Press.

Lea, J. 2009. “Liberation or Limitation? Understanding Iyengar Yoga as a Practice of the Self." Body and Society 3 (15): 71-92. doi:10.1177/1357034X09339100.

Lea, J., C. Philo, and L. Cadman. 2016. “It's a Fine Line between ... Self Discipline, Devotion and Dedication': Negotiating Authority in the Teaching and Learning of Ashtanga Yoga." Cultural Geographies 23 (1): 69-85. doi:10.1177/1474474015569993.

Lea, J., L. Cadman, and C. Philo. 2015. "Changing the Habits of a Lifetime? Mindfulness Meditation and Habitual Geographies.” Cultural Geographies 22 (1): 49-65. doi:10.1177/1474474014536519.

Leledaki, A. 2007. "Inner and Outer Journeys: A Qualitative Life History of Modern Yoga and Meditation as Body-SelfTransforming Pedagogies.” PhD diss., University of Exeter.

Lerner, E. 1977. A Journey of Insight Meditation. New York: Shocken Books.

Macy, J. 1991. Mutual Causality in Buddhism and General Systems Theory. Albany, NY: State University of New York Press.

Manga, G. 2008. "Interbeing Autonomy and Economy: Toward Enduring Social and Ecological Justice." Human Architecture: Journal of the Sociology of Self-Knowledge 6 (3): 113-127. http://scholarworks.umb.edu/human architecture/vol6/iss3/16.

Manning, E. 2010. “Always More Than One: The Collectivity of a Life.” Body \& Society 16 (1): 117-127. doi:10.1177/ $1357034 X 09354128$.

McCormack, D. P. 2002. “A Paper with an Interest in Rhythm.” Geoforum 33 (4): 469-485. doi:10.1016/S0016-7185 (02)00031-3.

Mckay, F. 2013. "Psychocapital and Shangri-Las: How Happiness Became Both a Means and End to Governmentality." Health, Culture and Society 5 (1): 36-50. https://hcs.pitt.edu/ojs/index.php/hcs/article/view/132/160.

McMahan, D. 2008. The Making of Buddhist Modernism. New York: Oxford University Press.

Mol, A. 2002. The Body Multiple: Ontology in Medical Practice. Durham, NC: Duke University Press.

Naess, A. 1973. “The Shallow and the Deep, Long-range ecology Movement. A Summary." Inquiry 16 (1): $95-100$. doi:10.1080/00201747308601682.

Naess, A. 1984. "Identification as a Source of Deep Ecological Attitudes." In Deep Ecology, edited by Michael Tobias, 265-270. San Diego, CA: Avant Books.

Naess, A. 1987. "Self-Realization. An Ecological Approach to Being in the World." The Trumpeter 4 (3): 35-42. http:// trumpeter.athabascau.ca/index.php/trumpet/article/view/623/992.

Pagis, M. 2009. “Embodied Self-Reflexivity.” Social Psychology Quarterly 72 (3): 265-283. doi:10.1177/019027250907200308.

Philo, C., L. Cadman, and J. Lea. 2014. "New Energy Geographies: A Case Study of Yoga, Meditation and Healthfulness." Journal of Medical Humanities 36 (1): 35-46. doi:10.1007/s10912-014-9315-3.

Pickering, A. 1995. The Mangle of Practice - Time, Agency \& Science. Chicago, IL: Chicago University Press.

Pickering A. 2007. "Ontological Theatre - Gordon Pask, Cybernetics, and the Arts." Cybernetics \& Human Knowing 14 (4): 43-57.

Pickering, A. 2010. The Cybernetic Brain: Sketches of Another Future. Chicago: University of Chicago Press.

Preston, D. L. 1981. “Becoming a Zen Practitioner.” Sociological Analysis 42 (1): 47-55. doi:10.2307/3709701.

Queen, C., and S. King. 1996. Engaged Buddhism. Albany: State University of New York Press.

Rose, N. 1998. Inventing Our Selves. Cambridge: Cambridge University Press.

Rose, N. 2007. The Politics of Life Itself - Biomedicine, Power and Subjectivity in the Twenty-First Century. Princeton, NJ: Princeton University Press.

Scarry, E. 1985. The Body in Pain: The Making and Unmaking of the World. Oxford: Oxford University Press. 
Seed, J., J. Macy, and P. Fleming. 1988. Thinking Like a Mountain - Towards a Council of All Beings. Philadelphia, PA: New Society.

Sessions, G. 1984. "Ecological Consciousness and Paradigm Change.” In Deep Ecology, edited by Michael Tobias, 2844. San Diego, CA: Avant Books.

Shanon, B. 2010. "The Epistemics of Ayahuasca Visions.” Phenomenology and the Cognitive Sciences 9 (2): $263-280$. doi:10.1007/s11097-010-9161-3.

Shapiro, D. H. 1984. "Overview: Clinical and Physiological Comparison of Meditation with Other Self-control Strategies." In Meditation - Classic and Contemporary Perspectives, edited by Deane H. Shapiro, and Roger Walsh, 5-12. New Brunswick: AldineTransaction.

Shaw, R. 2015. "Bringing Deleuze and Guattari Down to Earth through Gregory Bateson: Plateaus, Rhizomes and Ecosophical Subjectivity." Theory, Culture and Society 32 (7-8): 151-171. doi:10.1177/0263276414524451.

Shusterman, R. 1999. "Somaesthetics: A Disciplinary Proposal." The Journal of Aesthetics and Art Criticism 57 (3): 299-313. doi:10.2307/432196.

Smallwood, J., M. Obonsawin, and D. Heim. 2003. “Task Unrelated Thought: The Role of Distributed Processing.” Consciousness and Cognition 12 (2): 169-189. doi:10.1016/S1053-8100(02)00003-X.

Stanley, S. 2012. "Mindfulness: Towards a Critical Relational Perspective." Social and Personality Psychology Compass 6 (9): 631-641. doi:10.1111/j.1751-9004.2012.00454.x.

Stanley, S. 2013. "From Discourse to Awareness: Rhetoric, Mindfulness, and a Psychology without Foundations." Theory \& Psychology 23 (1): 60-80. doi:10.1177/0959354312463261.

Stengers, I. 2008. "Experimenting with Refrains: Subjectivity and the Challenge of Escaping Modern Dualism." Subjectivity 22: 38-59. doi:10.1057/sub.2008.6.

Szerszynski, B. 2014. "Liberation Through Hearing in the Planetary Transition: Funerary Practices in Twenty-SecondCentury Mangalayana Buddhism.” In Grain Vapor Ray: Textures of the Anthropocene, edited by Katrin Klingan, Ashkan Sepahvand, Christoph Rosol, and Bernd M. Scherer, 149-164. Cambridge: MIT Press.

Thrift, N. 2000. "Still Life in Nearly Present Time: The Object of Nature." Body and Society 6 (3-4): 34-57. doi:10.1177/ $1357034 X 00006003003$.

Thrift, N. 2004. "Intensities of Feeling: Towards a Spatial Politics of Affect.” Geografiska Annaler Series B: Human Geography 86 (1): 57-78. doi:10.1111/j.0435-3684.2004.00154.x.

Varela, F., and J. Shear. 1999. The View from Within - First-Person Approaches to the Study of Consciousness. Bowling Green: Imprint Academic.

Venn, C. 2010. "Individuation, Relationality, Affect: Rethinking the Human in Relation to the Living." Body and Society 16 (1): 129-161. doi:10.1177/1357034X09354770.

Whitehead, M., R. Lilley, R. Howell, R. Jones, and J. Pykett. 2015. “(Re)Inhabiting Awareness: Geography and Mindfulness.” Social and Cultural Geography 17 (4): 553-573. doi:10.1080/14649365.2015.1089590.

Zizek, S. 2005. "Revenge of Global Finance." In These Times, May 21. Accessed 22 February 2017. http://inthesetimes. com/article/2122/revenge_of_global_finance. 